\title{
THE REGULATION OF THE SOLICITATION OF PROXIES: SOME REFLECTIONS ON CORPORATE DEMOCRACY
}

\author{
SHeidon E. Bernstein* and Henry G. Fischer $\dagger$
}

$\prod$ 1HE Securities and Exchange Commission has recently amended its regulations concerning the solicitation of proxies. ${ }^{x}$ It is the purpose of this article to discuss some of the more important aspects of these regulations and the effect of certain amendments. But, in order better to understand the aims and purpose of statutory and administrative regulations of the solicitation of proxies, one should appreciate the separation of management and ownership in the modern corporation. ${ }^{2}$

Prior to the adoption of Section I4 of the Securities Exchange Act of I934, the solicitation of proxies was controlled, or it might be better described as uncontrolled, by appropriate state law. State statutes and decisions with regard to the furnishing of adequate information and the limitation of authorizations requested in such solicitation, where not completely absent, were vague and doubtful. ${ }^{3}$ The general practice was one of the solicitation of unlimited discretionary authorizations, sometimes to be good for a period of years.

It must be assumed that state statutes providing for stockholders' meetings were designed to allow stockholders to act in concert with other stockholders on matters which under corporate law were placed in their control. As corporations grew ownership became more dispersed; "democracy under a tree" became impossible; and the function of stockholders'

* Attorney, Securities and Exchange Commission.

$\dagger$ Attorney, Securities and Exchange Commission; Lecturer in Law, Catholic University of America.

This article represents the opinion of the authors, and is not to be construed in any manner as an expression of the Securities and Exchange Commission.

x The amendments took effect February 15, 1940. A discussion of the amendments may be found in Sec. Ex. Act Rel. 2376 (1940).

The words "proxy" or "proxies" will be used throughout this article generally to include proxies, consents, and authorizations, except as otherwise indicated in the text.

2 For able expositions of this separation, see Berle and Means, The Modern Corporation and Private Property (1932); SEC, Report on Work, Activities, Personnel, and Functions of Protective and Reorganization Committees, pt. VII (1938).

3 See Regulation of Proxy Solicitation by the SEC, 33 IIl. L. Rev. 9 I4 (1939). 
meetings became more difficult to achieve. It is generally recognized that in the larger corporations the stockholders' meeting is now only a necessary formality; that stockholder expression can only be had by the statutory device of proxy. As a result, within limitations, realistically the solicitation of proxies is today the stockholders' meeting.

Berle and Means in discussing the relation of control and ownership in modern corporations state that:

Where "control" is in the hands of the Board of Directors because stock is widely dispersed, and because the Directors are able to control the sending out of proxies year by year, it is evident that the relationship is still more subtle. On the one hand, the Directors are bound to use their powers as fiduciaries for the stockholders-this, in their quality as Directors. On the other hand, the proxies for the shareholders will cast the stockholder's vote at the meeting, as agents for the shareholders (a proxy is merely a power of attorney after all), and in this process they are acting for the shareholders. Since the proxy or agent is in legal theory a representative of the shareholder, while in fact he is an individual under the domination of the Board of Directors, there is almost inevitably a division of interest. Legally, the proxy is an agent for the shareholder and necessarily under a duty of fidelity to him. Factually, he is a dummy for the management, and is expected to do as he is told. Indeed, proxies are often clerks in the management, perhaps assisted by the company's attorney. The vote when mobilized really represents the will of the Directors.4

It thus became increasingly evident prior to the adoption of the Securities Exchange Act that the management of the modern corporation had made of the proxy machinery a self-perpetuation and a self-approval device creating what might be described as an "illiterate" corporate ownership; that the use of the proxy machinery was deemed a privilege to be exercised at the expense of the corporation solely by its managers. ${ }^{5}$ In this corporate drama the corporate meeting and the proxy device did not play the role purportedly cast for them by state statutes.

It became apparent that the proxy machinery could not replace the stockholders' meeting as a device by which control would be exercised by the stockholders unless the stockholders were afforded reasonable disclosure of the subject matter to be acted on at stockholders' meetings and reasonable opportunity for individual expression.

To meet these needs Congress enacted Section I4 of the Securities Exchange Act of $1934 .^{6}$ The views of the draftsmen of this section may be drawn from a committee report stating:

In order that the stockholder may have adequate knowledge as to the manner in which his interests are being served, it is essential that he be enlightened not only as

4 Berle and Means, op. cit. supra note 2, at 244-5.

5 See SEC, op. cit. supra note 2, pt. I (1937), and pt. VII (1938).

${ }^{6} 48$ Stat. 895 (1934), I5 U.S.C.A. $\& 78$ (Supp. 1938). 
to the financial condition of the corporation, but also as to the major questions of policy, which are decided at stockholders' meetings. Too often proxies are solicited without explanation to the stockholder of the real nature of the matters for which authority to cast his vote is sought.7

This report together with testimony before the Congressional committee, ${ }^{8}$ may be taken to mean that the Congress appreciated the demonstrated need for regulation aimed at securing disclosure with respect to solicitations of authority from the nation's security holders.

In view of suggestions appearing later in this article ${ }^{9}$ for expansion of disclosure regulation to matters not dependent upon solicitation, it is to be noted that the Congressional expression and the need for adequate and fair disclosure to security holders connotes something of greater significance than the disclosure of information pertinent to solicitation of authority per se. The furnishing of information in connection with solicitation of authority is merely one aspect of this policy. We must assume that the desirability and indeed the security holder's need for current news of corporate affairs is not fully satisfied by existing requirements as to reports to stockholders ${ }^{\mathrm{x}}$ or the regulation of the solicitation of proxies alone.

The history of commission regulation pursuant to authority granted in Section $\mathrm{r}_{4}$ of the Securities Exchange Act has been one of careful expansion based upon experience and demonstrated needs. The exercise of authority has been confined to Section I4(a) dealing generally with solicitation of proxies, consents and authorizations. The authority granted by Section $\mathrm{I4}(\mathrm{b})$ has, as yet, not been exercised. ${ }^{\mathbf{I x}}$

7S. Rep. I455, 73d Cong. 2d Sess., at 74 (x934).

${ }^{8}$ See H.R. Hearing on H.R. $785^{2}$ and $8720,73^{d}$ Cong. $2 d$ Sess., I 38 et seq. (I934); see also SEC, op. cit. supra note $r$.

9 See discussion at pp. $24 \mathrm{I}-2$ infra.

so See discussion in Kaplan and Reaugh, Accounting, Reports to Stockholders, and the SEC, 48 Yale L. J. 935 (I939).

II Section I4 provides: "(a) It shall be unlawful for any person, by the use of the mails or by any means or instrumentality of interstate commerce or of any facility of any national securities exchange or otherwise to solicit or to permit the use of his name to solicit any proxy or consent or authorization in respect of any security (other than an exempted security) registered on any national securities exchange in contravention of such rules and regulations as the Commission may prescribe as necessary or appropriate in the public interest or for the protection of investors.

"(b) It shall be unlawful for any member of a national securities exchange or any broker or dealer who transacts a business in securities through the medium of any such member to give a proxy, consent, or authorization in respect of any security registered on a national securities exchange and carried for the account of a customer in contravention of such rules and regula- 
On September 24, I935, the Securities and Exchange Commission promulgated its first proxy rules referred to as the LA rules. These rules merely required, in addition to certain items of general information, a brief description of the matters in respect of which the solicitation was made without any specification of the particular items to be included in such description. The rules emphasized stockholders' informational needs although they did contain in addition the equivalent of the rule now designated as Rule X-14A-6.22

The next stage in regulation by the commission was the promulgation of Regulation X-I4 on August I, I938. That regulation, in addition to expanding the required items of general information, specified with particularity items of information to be furnished those solicited concerning the matters in respect of which authority was sought. Equally as important, however, the stockholder's need for expression was recognized in Rule $\mathrm{X}-\mathrm{x}_{4} \mathrm{~A}-2,{ }^{\mathrm{x} 3}$ which required, with certain limitations, that the person solicited be given the means to specify the action which he desired taken pursuant to his proxy.

The experience gained in a year's operations under Regulation X-I4 has led to amendment, not only in the informational aspects of the regulation but, of greater significance, in the opportunity for security holder expression. In the following pages the writers will not attempt an exhaustive discussion of Section I4(a) of the Securities Exchange Act or the rules thereunder, but will merely attempt to outline some of the significant provisions and problems.

\section{PRESENT PRACTICE}

The keystone of Regulation X-I4 is the requirement that a proxy statement accompany each request for a proxy, consent or authorization ${ }^{\mathrm{x} 4}$ which is within the jurisdiction of the rules. ${ }^{\text {Is }}$ In addition, with certain exceptions, the person solicited must be given the opportunity to specify the action he desires taken pursuant to the proxy. ${ }^{16}$ The proxy rules, moreover, offer a vehicle whereby persons other than the management

tions as the Commission may prescribe as necessary or appropriate in the public interest or for the protection of investors."

In connection with the subject matter of Section $\mathrm{I}_{4}(b)$, however, see Rules $770-5$ of the New York Stock Exchange.

x2 See Appendix of Rules, p. 245 infra.

${ }_{33}$ See note 40 infra.

${ }_{4}$ See Rule X-I4A-I, Appendix of Rules, p. 243 infra. $\quad$ 25 See p. 239 infra.

${ }^{16}$ Rule X-r4A-2, Appendix of Rules, p. 243 infra; the most important of the exceptions is in regard to the election of directors and other officials. Another important exception is fully discussed at pp. 236 infra. 
may communicate with security holders by utilizing the services of the management. ${ }^{17}$ The rules, of course, offer certain appropriate exemptions. ${ }^{18}$

\section{MEANING OF "SOLICITATION"}

Before amendment, Regulation X-I4 defined "solicitation" to include "any request for a proxy whether or not such request is accompanied by or included in a written form of proxy." ${ }_{19}$ The first problem raised by this definition is whether the transmittal to security holders of a blank proxy form ${ }^{20}$ constitutes a solicitation. Many corporate managements have attempted by use of such a form to avoid the necessity of compliance with the proxy rules. The determination whether a solicitation is involved rests in the first place upon whether the term "request" includes implied as well as expressed requests. The commission has repeatedly decided that it does.

The second problem is to determine under what circumstances the transmission of a blank proxy constitutes an implied request, i.e. a solicitation. In a number of cases presented to the commission the blank proxy has been accompanied by a letter of transmittal, sometimes expressly professing not to be a solicitation and generally signed by a person or persons interested in the purpose covered by the proxy. In some cases an annual report or document containing a roster of officers or directors constituting the management which sent the proxy is included with the proxy form. It may be inferred here that a solicitation is intended in that the only means by which an uninformed security holder may cast his vote by use of the proxy form is to authorize its use to one of the persons named in the materials accompanying the proxy form; the knowledge of this result would appear to be imputable to persons responsible for the transmittal. In the recent amendment of the proxy rules the interpretations discussed above are presumably incorporated in the redefinition of solicitation to include "the furnishing of a form of proxy to security holders under circumstances reasonably calculated to result in a procurement of proxies." Where the proxies are not needed either for purposes of voting or for a

27 Rule X-I4A-6, Appendix of Rules, p. 245 infra.

${ }^{18}$ See Rule $\mathrm{X}-\mathrm{I}_{4} \mathrm{~A}-7$, ibid., p. 246 infra. In addition to the exemptions provided for in the rules, certain statutes expressly exempt solicitations within the purview of their provisions. See, e.g., § 77(f), Chapter VIII, 49 Stat. I969 (r936), II U.S.C.A. § 205 (Supp. rg).

19 Rule X-r $4 \mathrm{~A}-9$ (b) before amendment of Regulation X-r4.

${ }^{20}$ By "blank proxy form", is meant a form of proxy which requires the person solicited to fill in the names of his agents or proxies.

2x Rule X-14A-8(b) as amended, Appendix of Rules, p. 246 infra. 
quorum, their transmission may be interpreted as a mere accommodation to the security holder and therefore not a solicitation.

Another problem involved in the definition of solicitation is that of determining when a solicitation begins. ${ }^{22}$ In the ordinary situation the fact of solicitation is pretty clearly defined. There are, however, situations where persons interested in ultimately making an express solicitation of proxies make use of what might be termed "build-up" material which expounds on the matters in respect of which solicitation later occurs. Sometimes the "build-up" material expressly denies that it constitutes a solicitation, or it may refer to a contemplated express solicitation. In any event it seems clear that the transmission to security holders of a document containing information at the time of mailing intended to create a disposition favoring a matter upon which a subsequent request for a proxy is to be made, would constitute the commencement of solicitation for the purpose of Regulation X-I4. The line is necessarily vague since solicitation is a matter of intention but one where intention must be determined from results reasonably foreseeable. ${ }^{23}$

\section{MEANING OF "PROXX, CONSENT, OR AUTHORIZATION"}

The definition of "proxy" is well enough established by corporate law and practice as not to warrant any extended discussion here. Unfortunately this cannot be said as to the terms "authorization" and "consent." Nowhere in the legislation or the legislative history are these terms discussed or defined. Evidently, however, the terms were intended to encompass situations such as solicitations in reorganization proceedings, voluntary or involuntary, to obtain authority to represent the security holder or to bind the security holder to a developed plan of reorganization. ${ }^{24}$ The terms as used in the statute apparently have no more definite connotation than as loosely employed in reorganization practice. In that practice the terms defy definition except in their customary application.

In the opinion of the authors, Congress had in mind the need of disseminating adequate information to security holders in all those situations where either the corporate management or outside groups bargained with security holders to affect the latters' rights. ${ }^{25}$ Thus for example, where a

${ }^{22}$ This problem is important in order to determine: ( $\mathrm{r}$ ) when to file under Rule $\mathrm{X}-\mathrm{I}_{4} \mathrm{~A}-4$; (2) when the machinery provided in Rule $X-I_{4} A-6$ is available; and (3) when the disclosure requirements must be conformed with.

${ }_{23}$ Ill. L. Rev., op. cit. supra note 3 , at gr5 et seq. (I939).

${ }_{24}^{4}$ In connection with this type of solicitation, the statutory exemptions and those provided in Rule $\mathrm{X}-\mathrm{I} 4 \mathrm{~A}-7$ should be noted. Many situations of this type, however, are not exempt from Regulation X-I4.

${ }^{25}$ See SEC, op. cit. supra note 5 , pt. VII. 
reorganization committee solicits a power of attorney to represent security holders in a judicial reorganization the solicitation would appear to necessitate adequate disclosure.

Similarly, the solicitation by the management of the acceptance of a voluntary plan of reorganization by bondholders would appear to require full information as a basis of arriving at a reasonable determination whether or not to accept. Such a solicitation is a typical solicitation of "consents."

Tllustrative of the type of case in which the amorphous concept of consent presents difficulty, is that where a management solicits from its bondholders tenders ${ }^{26}$ of bonds. There is no patent similarity between such a request and a request that a plan of reorganization be approved. In both cases the management solicits the bondholders to agree to an exchange of rights. In the one case bondholders may for instance be asked to offer to accept a new security with an earlier maturity date; in the other the bondholders are asked to offer a security for cash, i.e., to accept immediate acceleration. In both situations, therefore, the bondholder is asked to "consent" to a "sale." Analytically then only one important difference exists between the two situations. In the tender situation the bargaining is normally with each stockholder as an individual and decision is not contingent on the action of the group as is generally the case in voluntary reorganizations.

Section I4, it must be remembered, was enacted because of the need for disclosure. But the need for disclosure is more marked when the solicitation is of assent to tender than when it is of assent to voluntary reorganization since in the latter case some criteria for judging the value of the offer are customarily supplied the security holder.

\section{CONTENTS OF THE PROXY STATEMENT}

The proxy statement is the instrument of disclosure which must accompany or precede a request for a proxy..$^{28}$ The regulation, in addition to items of general information such as those concerning persons making

\footnotetext{
${ }^{26}$ A typical solicitation of a "tender" would be a communication requesting bondholders to offer to sell to the management their bonds-the security holder to set the price of the offer, the management to accept or refuse at will.

${ }^{27}$ In accepting a plan of reorganization, the security holder is offering to modify or exchange his security. This is a sale which normally will be subject to the disclosure requirements of either the Securities Act of 1933 or Regulation X-I4. The tender situation also involves a modification of the rights of security holders, and is a sale. But since the soliciting party is not the seller within the definition of Section 2 of the Securities Act of 1933 , if the concept of "consent" does not extend to the "tender" case, the transaction avoids all disclosure requirements.
}

${ }^{28}$ Rule X-I4A-I, Appendix of Rules, P. 243 infra. 
the solicitation, ${ }^{29}$ requires disclosure of basic information concerning matters to be acted upon pursuant to the proxy. ${ }^{30}$ While no general exposition of these requirements will be made, it seems desirable to mention that certain changes have been effected by the recent amendments. For instance the schedule of information relating to election of directors has undergone a complete revision ${ }^{3 \mathrm{x}}$ and new schedules have been added covering the election of auditors ${ }^{32}$ and the restatement of any asset, capital or surplus account of the issuer. ${ }^{33}$

a) Stockholder expression. - In connection with the recent amendments a major step forward has been taken in giving the stockholder a medium of expression to his fellow investor. Here three provisions of Regulation $\mathrm{X}-\mathrm{I}_{4}$, Rules X-I4A-2, X-I4A-8 (i) and Item I6 of Schedule A, are important.

During the past year the commission has interpreted the unamended Regulation $\mathrm{X}-\mathrm{I}_{4}$ in a way that has achieved some highly significant results. In particular its interpretation of Rule X-I4A-5 $5^{34}$ has created new possibilities of stockholder democracy. Suppose that a stockholder informs the management that he proposes to raise on the floor of the meeting a motion to amend the by-laws to allow stockholders to elect the auditors from year to year. We shall assume that the stockholder may properly raise this matter on his own initiative under state law. The management receives this notice before soliciting proxies on its own behalf in regard to the election of directors. For the purpose of the following discussion the proposed election of directors will be referred to as Matter A; the proposed amendment of the by-laws, Matter B. It was apparently held in several cases, last year, that a proxy statement transmitted to stockholders by the management which failed to indicate that the management

${ }^{29}$ Schedule $14 \mathrm{~A}$, Items $\mathrm{I}-5$, as amended r940.

${ }^{30}$ Schedule $\mathrm{r} 4 \mathrm{~A}$, Items $6-\mathrm{I} 6$, as amended $\mathrm{r} 940$. Items $6, \mathrm{I}_{3}$ and $\mathrm{I} 6$ are reprinted in Appendix of Rules, pp. $247-9$ infra.

${ }^{3 x}$ Schedule 14 A, Item 6(a), ibid., p. 247 infra.

${ }^{32}$ Schedule I4A, Item 6(b), ibid., p. 249 infra.

33 Schedule ${ }_{4} 4 A^{*}$, Item $I_{3}$, ibid.

34 Rule $\mathrm{X}-14 \mathrm{~A}-5$; unamended, read:

"No solicitation subject to Section $x_{4}(a)$ of the Act shall be made by means of any form of proxy, notice of meeting, or any other communication containing any statement which, at the time and in the light of the circumstances under which it is made, is false or misleading with respect to any material fact, or omits to state any material fact necessary in order to make the statements therein not false or misleading."

For amended Rule X-I4A-5, see Appendix of Rules, p. 245 infra. The amendments are not material to discussion herein. 
knew a stockholder would bring before the meeting Matter $B$ would be misleading under some circumstances. ${ }^{35}$

It also seems true with respect to the same situation, that, even if notice were given in the proxy statement that such a stockholder intended to raise Matter $B$ at the meeting, the proxies received by the management pursuant to such a proxy statement could not be voted upon that matter unless the disclosure requirements of Regulation X-I4 were complied with and the persons solicited were given an opportunity pursuant to Rule X-I4A-2 to specify their desire in regard to that matter. Nothing in Regulation X-I4, before amendment, required the management to comply with Rule X-I4A-2 as to Matter B and where the management chose not to do so stockholders giving them proxies were disfranchised as to that matter. A management averse to Matter B would generally choose this course and defeat Matter $B$ on the floor of the meeting by voting management shares personally represented.

Regulation $\mathrm{X}-\mathrm{I}_{4}$ as amended attempts to enfranchise proxy givers with regard to Matter B. It will be noted that Rule X-I4A-2 provides that means be afforded the person solicited to specify the action desired to be taken pursuant to the proxy on each matter or "... . matters . . . to be acted upon pursuant to the proxy." Regulation X-I4 unamended contained no definition of this phrase and it was apparently assumed to mean matters upon which the management intended to use the proxies for purposes of a vote. The amended regulation has now defined the phrase, in Rule X-I4A-8(i), to include both

matters which the persons making the solicitation intend to present and any matters which the persons making the solicitations are informed other persons intend to present for action at such meeting, in the event persons making such solicitation intend that the proxies shall be used for the purposes of a vote upon such matters or for the purposes of a quorum supporting such vote. $\ldots . .^{36}$

The effect of this provision is to require a management to malse appropriate disclosure and to afford security holders the franchise provided by Rule X-I4A-2 in regard to any matter which it is informed another will and can properly raise at the meeting. This is a significant step towards corporate democracy in that it gives security holders a reasonable medium of obtaining the expression of fellow security holders.

Thus to employ our A-B example, the management intending to raise

3s The test apparently was whether, in the particular case, the knowledge of Matter B, together with the knowledge that the management was not soliciting expression as to Matter B, would substantially have affected the judgment of security holders on Matter A. See Dean, Non-Compliance with Proxy Regulations, 24 Corn. L. Q. 483 (r939).

${ }^{36}$ Appendix of Rules, p. 247 infra; italics supplied. 
only Matter A is informed by a stockholder that he intends to raise Matter $B$. The proxies solicited by the management are necessary to establish a quorum for voting on Matter A. It would appear that a quorum once established at a stockholders' meeting continues for all proper purposes of the meeting ${ }^{37}$ and that a management soliciting proxies for a quorum and vote at a meeting must be held to appreciate this. Thus, if Matter B is proper to be raised from the floor, the management having established a quorum with reference to Matter $A$ has also established a quorum for Matter B. Matter B would, therefore, fall within the definition of the matters to be acted upon at the meeting.

The only determination left to the management in the above situation is whether Matter B is one which may properly ${ }^{38}$ be raised by a stockholder at the meeting or one which may properly and will be declared out of order at the meeting. Item $I 6^{39}$ has the effect of requiring the management, in the situation where it intends to declare Matter B out of order, to disclose the matter and its intended disposition.

b) Solicitation of discretionary authority.-In connection with Rule $\mathrm{X}-\mathrm{I} 4 \mathrm{~A}-2$ one other matter should be noted. Under the rule prior to amendment,$^{40}$ the problem often arose as to the extent of discretionary authority which could be sought. Several situations were presented. For

37 It seems clear that a stockholder personally present at a meeting cannot break a quorum by withdrawing "without justification." Hexter v. Columbia Baking Co., $x 6$ Del. Ch. 263, I45 Atl. II5 (I929); it also seems clear that the same rule applies in the case of a proxy-even though his authorizations have not been filed-where the authorizations are general. Duffy

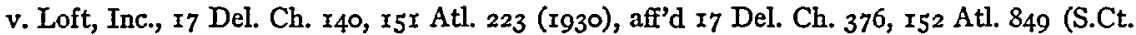
I930). A proxy with limited authorizations would seem to be in the position of a stockholder present at the meeting but abstaining from voting on particular matters. There should be, therefore, no distinction between this situation and those above. Cf. Petroleum Rights Co. v. Midland Royalty Co., I67 Atl. 835 (Del. Ch. I933); cf. Commonwealth ex rel. Sheip v. Vandegrift, 232 Pa. 53, 8r Atl. 153 (rgrr).

${ }^{38}$ Very little case law exists as to what a stockholder may properly raise from the floor. Here is a focal point of the division of responsibility between the management and stockholders. For a discussion, see Dean, op. cit. supra note 35 .

39 Appendix of Rules, p. 249 infra.

$4^{\circ}$ Rule X-I4A-2, unamended, read:

No solicitation subject to Section $I_{4}$ (a) of the Act shall be made unless (a) means shall have been provided whereby the person solicited is afforded an opportunity to specify, in a space provided in the form of proxy or otherwise, the action which such person desires to be taken pursuant to the proxy on each matter, or each group of related matters as a whole, described in the proxy statement as intended to be acted upon, other than the election of directors or other officials, and (b) the authority conferred as to each such matter or group of matters is limited by the specification so made. Nothing in Regulation X-I4 shall prevent the solicitation of a proxy conferring discretionary authority with respect to matters as to which the person solicited does not make the specification provided for above, or with respect to matters not known or determined at the time of the solicitation, or with respect to elections of directors or cther officials. 
instance authority might be sought to vote the proxy for five directors whereas only four nominees were named and discretionary authority as to a fifth contemplated. Rule X-14A-2 has been amended expressly to preclude discretionary authority of this type. ${ }^{4 x}$

There are other situations, however, not affected by the amendment, in which the problem of discretionary authority exists. Thus, for example, a management may present a pension plan or a recapitalization plan to be acted upon at a stockholders' meeting. All disclosure requirements of Regulation $\mathrm{X}-\mathrm{I}_{4}$ are met in the soliciting material as to the nature of the proposed plan. The stockholders are permitted to specify their preference in the proxy form in accordance with Rule X-I4A-2. Subsequently to the solicitation, however, an unanticipated contingency arises which makes necessary some adjustments in the proposed plan. If the authorizations obtained are to limit the management to vote upon the plan only as presented in the proxy statement, a resolicitation would be required, if violation of Rule X-I4A-5 is to be avoided. Rule X-I4A-2, therefore, provides that, in such a situation, discretionary authority may be sought as to matters not known or determined at the time of the solicitation. In view of the fact that unanticipated contingencies arising subsequently to solicitation are matters clearly not within the control of the soliciting persons, the circumstances set out above fall within this provision, and, therefore, the form of authorization may be cast to allow the desired flexibility.

The following is an illustration of another type of situation intended to be covered by Rule X-I4A-2. A management desires the authorization and issuance of new securities. It is clear that financing being what it is, market conditions obviously not within the control of the management necessitate that final arrangements as to offering price, underwriting fees, interest rates, etc., be made at the latest possible moment. Since arrangement for and solicitation of proxies in any sizeable organization is a timeconsuming process, the management may not be in a position to give final details at the time of solicitation. Obviously, therefore, at the time of solicitation the matters referred to are beyond the control of the soliciting party to know or determine. In this situation Rule X-I4A-I(b) is meant to apply. That rule reads:

Information as to matters to occur or to be determined in the future need be given only in terms of present intention, but in such case there shall be set forth, to the extent practicable, the maximum and minimum limits of the authority to be conferred concerning each such matter.

4 Amended Rule $\mathrm{X}-x_{4} \mathrm{~A}-2$, Appendix of Rules, p. 243 infra, has this provision:

".... No authority shall be sought to vote the proxy upon the election of any person to any office (inclusion of that of auditors and member of a committee to select auditors) for which a bona fide nominee is not named in the proxy statement." 
In this situation then the management is to be permitted discretionary authority as to price, fees, interest rates, etc., within the limits set out in accordance with Rule X-I4A-r(b).

In connection with Rule X-I4A-2 and the authorization of securities, it is to be noted that corporation laws generally do not require stockholder approval of the time or terms of issuance although such issuance must be authorized by a vote of stockholders. A corporate management may thus determine to solicit the authorization for issuance without then contemplating the time or terms of issuance. A statement to this effect is all that can be required under Rule X-I4A-I (b) and Rule X-I4A-2 does not come into play in respect of the time and terms of issuance because, as indicated, no authority for issuance generally need be sought under state law.

\section{ENFORCEMENT}

The value of any statute lies in and may be measured in part by its enforceability. Its fulfillment of community needs is proved by the co-operation evidenced in its administration. By and large the Securities and Exchange Commission has found the corporate community desirous of carrying out its proxy regulations, and investors have vouched for the assistance rendered thereby.

\section{x. WAITING PERTOD}

The problem of administration of the proxy rules is chiefly one of interpretation and adjustment of the facts of particular situations to the requirements of the rules. The experience of the staff of the commission's proxy unit has demonstrated that good faith of those drafting solicitation material is often handicapped by the lack of familiarity with the rules. Under old Regulation X-I4, and prior to this under the LA Rules, soliciting parties were not required to file their material with the commission until solicitation in fact had begun. The amendments have added a "waiting period" of ten days, i.e., the material must be filed with the commission not less than ten days before solicitation begins. ${ }^{42}$

Before a waiting or examining period was provided, those who were not aware of the commission's stated offer to examine draft material often found themselves in the embarrassing position of having to resolicit, to send out additional informational material or to limit their use of proxies because of inadvertent deficiencies brought to their attention by the commission. It is hoped that the ten day waiting or examining period provided by the amendments to Regulation $\mathrm{X}-\mathrm{I} 4$ will give the commission the opportunity to catch many deficiencies before the persons soliciting have distributed their material. It should be noted that the provision for 
an "examining" period ( $I$ ) includes an acceleration clause to cover those special situations when there is a clear need for more immediate release of the soliciting material and (2) does not apply to supplementary solicitation material.

2. SANCTIONS

It is usually the case that a mere warning of the noted deficiencies will suffice to induce their correction. But where necessary the commission has substantial sanctions at hand, including ( 1 ) the injunction, (2) delisting, and (3) criminal proceedings.

It might be said that the commission, during its five year history of the regulation of proxy solicitation, has never had occasion to proceed either with a delisting proceeding or criminal action and only once has it had to seek an injunction. The principal function of these sanctions is to discourage violations of Section I4(a).

The sanctions available for violations of the proxy rules have received discussion elsewhere. ${ }^{43}$ The recent case in which the injunctive power was asserted, however, is deserving of discussion. In that case the District Court of the United States for the District of Massachusetts granted the commission an injunction. ${ }^{44}$ In the situation in question an "outside" group sought to gain the election to the position of managing director of a former managing director of the corporation. This soliciting group, purportedly a committee independent of the person whose election it was seeking, repeatedly used soliciting material not complying with the disclosure requirements of Regulation $\mathrm{X}-\mathrm{r} 4$ and allegedly containing false and misleading statements. After purportedly "curing" the situation by recalling the tainted proxies, further allegedly false and misleading soliciting literature was sent the corporations stockholders over the signature of the candidate.

The vital question before the court was whether the commission under Section 2I (e) of the Securities Exchange Act ${ }^{45}$ was entitled at most only to an injunction against a solicitation in contravention of its rules or whether the court could go further and enjoin the use of the tainted proxies. Literally, Section $2 \mathrm{I}(\mathrm{e})$ authorizes only an injunction against acts and practices constituting a violation of the act or the rules and regulations thereunder. As applied to Regulation X-I4 this would merely appear to entitle the commission to an injunction against solicitation in contravention of that regulation. But the impracticability of so restricting injunc-

${ }_{43}$ IIl. L. Rev., op. cit. supra note 3 , at 935 et seq.

44 SEC v. O'Hara Re-election (or Proxy) Committee, 28 F. Supp. 523 (D.C. Mass. 1939). ${ }_{45} 48$ Stat. 900 (r934), ${ }_{5}$ U.S.C.A. $\S 78 \mathrm{u}$ (Supp. r939). 
tive relief is evident. Solicitations which would necessitate the exercise of this sanction will not develop until in fact a solicitation has been made. If relief should be limited to an injunction against the very acts whose execution is the factor putting the commission on notice the right to injunctive relief would become meaningless. Moreover it would seem that the party soliciting in contravention should not be permitted the use of proxies so tainted. The commission appealed to the courts own equity powers flowing as proper adjuncts to necessary relief. To this the court responded:

Rule X-I4A-5 prohibits the solicitation of proxies by any communication containing a false or misleading statement. The rules and the act under which it was promulgated are concerned with the unlawful solicitation of proxies. The proxies that have been received as a consequence of the O'Hara letter are not valid proxies within the meaning of the Act. The use of proxies secured unlawfully cannot be countenanced by a court of equitable jurisdiction.

The court thus seemed determined to protect the stockholders' right to vote on the basis of honest disclosure of the facts by enjoining the exercise of proxies obtained in contravention of the commission's proxy rules and by enjoining the holding of the meeting until resolicitation. On the latter point the court stated:

Although counsel have urged that the defendant corporation be not compelled to further postpone its annual meeting, I must take notice of the fact that the shareholders, whose proxies are invalidated above, would, in effect, be disenfranchised if the annual meeting of the association were to be held on July $3 \mathrm{~d}$. An injunction may issue against the holding of the annual meeting before July 10, 1939, which is considered ample time to obtain and file new and valid proxies.

Many questions on the injunctive power remain even after this decision. For instance can the commission enjoin the action voted to be taken in the exercise of the tainted proxies? Or can the commission move to set aside such action already taken? To these questions no answer can as yet be given. ${ }^{46}$

\section{JURISDICTION-POSSIBLE AREAS OF EXTENSION}

While the regulation of the solicitation of proxies, consents and authorizations by the rules promulgated pursuant to Section I4(a) of the Securities Exchange Act of 1934 is one link in bridging the span between owner and manager in the modern corporation, it must not be assumed that this regulation serves completely to gain for security holders the information necessary to them in the ownership of their securities.

It should be remembered that the disclosure required by Section I4(a) and regulations thereunder relates only to matters in respect of which

${ }^{4}{ }^{6}$ Ill. L. Rev., op. cit. supra note 3 , at 938. 
authority is solicited. ${ }^{47}$ Furthermore Section I4(a) and Regulation X-I4, as amended, are further circumscribed.

Solicitations in respect of securities traded solely in the over-thecounter market go unbridled by virtue of Section I4(a) itself. If the regulation of proxy solicitation has any foundation, as presumably it has, surely the desirability of regulation or non-regulation cannot be contingent on the mere fact of listing on a national securities exchange. The Congress itself recognized the materiality of the over-the-counter market in Section 2 of the Securities Exchange Act, which sets out the necessity for regulation of security markets. ${ }^{48}$

It would appear that the present status of the jurisdiction of Section I4(a) constitutes a safeguard surrounding registered securities not given those traded solely in over-the-counter markets. The rationale of this limitation is not based on disparate needs. The total value of unregistered securities, while difficult to estimate, obviously bulks large in national finance; and, considered from the point of view of which type of security holder is the better informed concerning his investment, it can probably be said that the safeguard is at least equally needed with respect to such securities.

It would appear then that this limitation may be founded on ( $I$ ) a de-

${ }^{47}$ For a type of situation not within Section I4(a) but which should call for disclosure, see discussion relating to the authorization and issuance of securities at pp. $236-7$ supra.

$4^{8}$ "For the reasons hereinafter enumerated, transactions in securities as commonly conducted upon securities exchanges and over-the-counter markets are affected with a national public interest which makes it necessary to provide for regulation and control of such transactions and of practices and matters related thereto, including transactions by officers, directors, and principal security holders, to require appropriate reports, and to impose requirements necessary to make such regulation and control reasonably complete and effective, in order to protect interstate commerce, the national credit, the Federal taxing power, to protect and make more effective the national banking system and Federal Reserve System, and to insure the maintenance of fair and honest markets in such transactions:

(I) Such transactions

(a) are carried on in large volume by the public generally and in large part originate outside the States in which the exchanges and over-the-counter markets are located and/ or are effected by means of the mails and instrumentalities of interstate commerce;

(b) constitute an important part of the current of interstate commerce;

(c) involve in large part the securities of issuers engaged in interstate commerce;

(d) involve the use of credit, directly affect the financing of trade, industry, and transportation in interstate commerce, and directly affect and influence the volume of interstate commerce; and affect the national credit.

(2) The prices established and offered in such transactions are generally disseminated and quoted throughout the United States and foreign countries and constitute a basis for determining and establishing the prices at which securities are bought and sold, the amount of certain taxes owing to the United States and to the several States by owners, buyers, and sellers of securities, and the values of collateral for bank loans," 48 Stat. 88I (I934), I5 U.S.C.A. \& $78 \mathrm{~b}$ (Supp. I939). 
sire to lend constitutional support to federal regulation of proxy solicitation, and (2) the necessity of having some method of policing the ground covered by the statute and the rules thereunder.

Apropos of the former point, two constitutional arguments would appear available for the support of the Securities Exchange Act in its entirety. First is the recited necessity in the act for controlling a national business of the importance of the securities business. Secondly, the federal power over the mails and channels of interstate commerce would appear unquestioned. It is not our purpose here to enter into a discussion of these constitutional points. They are capably demonstrated by others. ${ }^{49}$ At one time it may have been difficult to recognize the national and extra local character of the securities business handled by the over-the-counter dealers but with the recent organization of these dealers pursuant to Section I $5 \mathrm{~A}$ of the Securities Exchange Act, this recognition would appear to have been made.

It may appear then that the organization of the over-the-counter markets has made more feasible an expansion of Section I4(a) to cover solicitations in respect of securities traded on the over-the-counter markets.

Another respect in which the jurisdiction of proxy regulation is limited relates to the manner of solicitation. Section $\mathrm{I}_{4}$ (a) covers solicitations "by the use of the mails or by any means or instrumentality of interstate commerce or of any facility of any national securities exchange or otherwise. ...." "so The commission, in Regulation X-I4, has limited its jurisdiction by cutting off the phrase "or otherwise." Again constitutional questions appear to lurk in the background. Since, however, a solicitation of any consequence will, in some phase, employ the mails or some channel of interstate commerce and since the regulation has been so interpreted as to comprehend any solicitation which in any phase employs such means, ${ }^{52}$ the Commission's action in eliminating the "or otherwise" to avoid constitutional embarrassment may have been advisable.

The effectuation of the policy inherent in Section I4(a) would appear to require that the disclosure contemplated by that section be extended by further legislation to corporate matters other than those related to solicita-

\footnotetext{
49 See briefs introduced as exhibits in S. Hearings on S. 3420, 73d Cong., 2d Sess., pt. 16 , at 7634 et seq.; and in H.R. Hearing on H.R. $785^{2}$ and 8720 , $73^{d}$ Cong., 2d Sess., at 916 et seq., 925 et seq. (1934).

so Italics added.

5x See Rule X-I4A-7(a), Appendix of Rules, p. 246 infra.

${ }^{2}$ Note judicial interpretation of similar provision in Mail Frauds statutes and Securities Act of 2933 .
} 
tion of authority per se. Of over twenty-four hundred companies whose securities were listed and registered in this country the Securities and Exchange Commission had filed with it proxy soliciting material only in respect of less than sixteen hundred companies in the fiscal year ended June I939. This discrepancy may be explained in part by the fact that corporation managements with quorums in their pocket, operating under law which obviates quorum worries ${ }^{53}$ or with quorums semi-assured adhered to a time worn practice of leaving the "outside" security holders in the dark as to the proceedings at corporate meetings and with respect to corporate elections.

The Congressional recognition of the obvious need of security holders for information as to management of their investment ${ }^{54}$ is the same regardless of whether the management of the corporation has a quorum problem or not. It would seem then unreasonable to limit the requirements of the dissemination of information to situations in which solicitation occurs. 55 To remedy this situation the power possessed by the commission under Section $I 9(b)^{56}$ to supervise the rules of the national securities exchanges might perhaps be employed to obtain appropriate disclosure.

In addition to the situation discussed above where meetings of stockholders are held without disclosure to the "outside" ownership, there are many other situations where corporate movements or conditions should be adequately and fairly reported to the ownership. Thus, for instance full annual reports of corporate condition, policies and program would seem to be in order. ${ }^{57}$ In addition, major current corporate activities such as the issuance of securities, capital investments, etc. not necessitating stockholder voice should be reported. Here the power which is vested in the commission by Rule Ig(b) might again be employed to advantage with respect to listed securities. It may be, however, that without the development of a similar program as to unlisted securities no further requirements as to listed securities should be attempted.

53 See e.g., Ohio Code Ann. (Throckmorton, I936), $\$ 8623-48$.

${ }^{4} \mathrm{~S}$. Rep., op. cit. supra note 7 .

ss In this connection, however, the New York Stock Exchange does require that security holders receive annual reports of the companies listed thereon, regardless of solicitation. But see Kaplan and Reaugh, op. cit., supra note to.

${ }^{56}$ Section $\mathrm{xg}(\mathrm{b})$ provides:

"The commission is further authorized . . . . by rules or regulations or by order to alter or supplement the rules of such exchanges in respect of .... (3) the listing or striking from listing of any security . . . " 48 Stat. 898-9 (x934), I5 U.S.C.A. \$ 78 s (Supp. 1939).

57 Insofar as securities exchanges presently require annual reports to security holders, see able discussion and analysis in Kaplan and Reaugh, op. cit. supra note ro. 


\section{APPENDIX OF RULES}

\section{REGULATION X-14, AS AMENDED}

(Items I, 2, 3, 7-I2, which are the same as in Regulation X-I4, unamended, have been omitted. Item $\mathrm{I}_{3}$ of the unamended Regulation is now Item I4, and Item $\mathrm{I}_{4}$ is Item 15.)

Rules Relating to Solicitation of Proxies, Consents, and Authorizations, InCluding SchedUle I4A As AMENDEd, EFFective February I5, I940

\section{Rule $X-r 4 A-I$. Proxy Statement}

(a) No statement need be made in the proxy statement in response to any item or subitem of Schedule $I_{4} \mathrm{~A}$ which is inapplicable. None of the items need be restated in the proxy statement, and the order of the items and subitems in the schedule need not be followed. Information required by more than one applicable item need not be repeated in the proxy statement.

(b) Any information required to be included in the proxy statement which is not known and not reasonably available to the persons making the solicitation may be omitted, if a brief statement of the circumstances rendering such information unavailable is made in the proxy statement. Likewise, information as to matters to occur or to be determined in the future need be given only in terms of present intention, but in such case there shall be set forth, to the extent practicable, the maximum and minimum limits of the authority to be conferred concerning each such matter.

(c) There may be omitted from the proxy statement any information contained in any document which has been furnished within a reasonable time in advance of the solicitation to each person solicited, if a clear reference is made to the place where such information appears. Any statement made in the proxy statement may be qualified by clear reference to any such document, or to any document which is on file with the Commission and with each exchange on which the securities are listed.

(d) In all cases in which past occurrences are to be consented to or acted upon pursuant to the proxy, the applicable items of Schedule I4A shall be read in the past tense, if appropriate.

(e) Unless the context clearly shows otherwise, whenever any fixed period of time in the past is indicated, such period shall be computed from the date of filing the proxy statement.

\section{Rule X-I4A-2. Duly To Provide Means by Which Desired Action Can Be Specified}

No solicitation subject to Section $\mathrm{I}_{4}(a)$ of the Act shall be made unless (a) means shall have been provided whereby the person solicited is afforded an opportunity to specify, in a space provided in the form of proxy or otherwise, the action which such person desires to be taken pursuant to the proxy on each matter, or each group of related matters as a whole, described in the proxy statement as intended to be acted upon, other than elections to office, and $(b)$ the authority conferred as to each such matter or group of matters is limited by the specification so made. Nothing in Regulation X-I4 shall prevent the solicitation of a proxy conferring discretionary authority with respect to matters as to which the person solicited does not make the specification provided for above, or with respect to matters not known or determined at the time of the solicitation, or with respect to elections to office: Provided, however, that no au- 
thority shall be sought to vote the proxy upon the election of any person to any office (inclusive of that of auditors and member of a committee to select auditors) for which a bona fide nominee is not named in the proxy statement.

\section{Rule X-I4A-3. Legibility of Soliciting Material}

Every printed proxy statement and form of proxy, and all related printed material furnished to the persons solicited in connection with any solicitation subject to section $\mathrm{I}_{4}(a)$ of the Act, other than documents not prepared in connection with the solicitation, shall be set in type not smaller than ro-point roman, at least 2-point leaded; except that financial statements may be set in type not smaller than 8-point roman, if necessary for convenient presentation.

\section{Rule X-I4A-4. Duty To File Material with Commission and Exchange}

(a) No solicitation subject to Section $\mathrm{r} 4(a)$ of the Act shall be made unless copies of the following material shall have been filed or mailed, in accordance with the provisions of paragraphs $(b),(c)$, and $(d)$, with or to the Commission, at its office in Washington, D.C., and with or to each national securities exchange upon which is listed any security in respect of which the solicitation is made-

(x) The proxy statement, the form of proxy, and any additional material intended to be furnished to security holders concurrently with the proxy statement.

(2) Any additional material relating to the same meeting or subject matter furnished to security holders subsequent to the furnishing of the proxy statement, exclusive of replies to inquiries from security holders requesting further information upon any aspect of the solicitation.

(3) Any document to which reference is made pursuant to Rule $\mathrm{X}-\mathrm{r} 4 \mathrm{~A}-\mathrm{r}$ (c) which has not been previously filed with the Commission and the appropriate exchange or exchanges.

(b) Three copies of the material described in paragraphs $(a)(\mathrm{r})$ and $(a)(3)$, the copies of the material described in paragraph $(a)(\mathrm{I})$ to be preliminary copies for the information of the Commission only and so marked, shall be filed with the Commission not later than ten days prior to the date definitive copies of the material described in paragraph $(a)(x)$ are first sent or given to any security holders, or, in respect of all or any part of the material described in paragraphs $(a)(\mathrm{I})$ and $(a)(3)$, not later than such lesser number of days prior to such date as the Commission, upon a showing of unusual circumstances, may determine: Provided, however, that the provisions of this paragraph shall not apply to material additional to the proxy statement and form of proxy intended to be furnished to security holders concurrently with the proxy statement.

(c) Three copies of the material described in paragraph (a)(r) or of any revision of such material, in the form in which such material is released to security holders, shall be filed with or mailed to the Commission, and with or to the appropriate exchange or exchanges, not later than the date such material is first sent or given to any security holders; and three copies of the material described in paragraph $(a)(2)$, in the form in which it is released to security holders, shall be similarly filed or mailed. Three copies of the material described in paragraph $(a)(3)$ shall be filed with or mailed to the appropriate exchange or exchanges not later than the date the material described in paragraph $(a)(I)$ is first sent or given to any security holders.

$(d)$ The material described in paragraphs $(a)(\mathrm{I})$ and $(a)(2)$, as transmitted to the 
Commission, whether in preliminary or definitive form, shall be accompanied by a statement indicative of the date upon which copies thereof are intended to be or are being released to security holders.

\section{Rule X-I4A-5. False or Misleading Statements}

No solicitation subject to Section $\mathrm{I}_{4}(a)$ of the Act shall be made by means of any form of proxy, notice of meeting, or other communication containing any statement which, at the time and in the light of the circumstances under which it is made, is false or misleading with respect to any material fact, or omits to state any material fact necessary in order to make the statements therein not false or misleading or necessary to correct any statement in any earlier communication with respect to the solicitation of a proxy for the same meeting or subject matter which has become false or misleading.

\section{Rule X-r4A-6. Duty of Issuer To Furnish Information and Mail Proxies at Request of Security Holder}

No solicitation subject to section $\mathrm{I}_{4}(a)$ of the Act shall be made by or on behalf of the issuer or its management, directly or indirectly, unless the issuer performs or has performed such of the following acts as may be duly requested by any record owner of any security of the issuer (hereinafter called "the applicant") with respect to the same subject matter or meeting:

(a) At the written request of the applicant, the issuer shall furnish the following information:

(I) A statement of the approximate number of the holders of record of any specified class of securities of which any of the holders have been or are to be solicited by or on behalf of the issuer or its management (as of any date selected in connection with such solicitation, or if none has been selected, approximately as of the date designated by the applicant), and the approximate number of any other holders of the specified class of securities who have been or are to be solicited by or on behalf of the issuer or its management; and

(2) An estimate of the cost of mailing a specified form of proxy or other communication to such holders.

Any information requested pursuant to this paragraph shall be mailed or otherwise furnished on or before the third business day after receipt of the written request.

(b) At the written request of the applicant, copies of any form of proxy or other communication furnished by the applicant shall be mailed by the issuer to holders of record (as of the date selected under $(a)$ ) of any specified class of securities of which any of the holders have been or are to be solicited by or on behalf of the issuer or its management, and to any other holders of the specified class of securities who have been or are to be solicited by or on behalf of the issuer or its management. Such material shall be mailed with reasonable promptness after receipt by the issuer of a tender of the material to be mailed, of envelopes or other containers therefor, of postage or payment for postage, and of reasonable reimbursement to the issuer of all expenses incurred in connection with such mailing or of a surety company bond satisfactory to the issuer in an amount sufficient to cover such expenses; except that such material need not be mailed prior to the first day on which the solicitation is made by or on behalf of the issuer or its management. 


\section{Rule $X-I 4 A-7$. Solicitations to Which Rules Are Not Applicable}

Notwithstanding any other provision in this regulation, the rules contained therein shall not apply to-

(a) Any solicitation made otherwise than by the use of the mails or by any means or instrumentality of interstate commerce or of any facility of any national securities exchange;

(b) Any solicitation of a proxy by any person in respect of securities carried in his name or in the name of his nominee, or held in his custody, if ( $\mathrm{I}$ ) such person receives no commission or remuneration for such solicitation, directly or indirectly, other than reimbursement of reasonable out-of-pocket expenses and clerical expenses, and (2) such person furnishes to the person solicited a copy of all soliciting material which the persons on whose behalf the solicitation is made are sending to other persons: Provided, however, That this exemption shall not be applicable to any solicitation by a voting trustee in respect of securities of which he is trustee;

(c) Any solicitation of a proxy by any person in respect of securities of which he is the beneficial owner;

(d) Any solicitation of a proxy evidenced by a certificate of deposit or other security which is registered under the Securities Act of r933;

(e) Any solicitation of an acceptance, conditional or unconditional, of a plan of reorganization under Chapter X of the Bankruptcy Act.

\section{Rule $X-14 A-8$. Definitions}

For the purposes of regulation $X-I 4$, unless the context otherwise requires-

(a) The term "proxy" includes every proxy, consent, or authorization within the meaning of section $\mathrm{I}_{4}(a)$ of the Act.

(b) The term "solicitation" includes ( $\mathrm{I}$ ) any request for a proxy, whether or not such request is accompanied by or included in a form of proxy, and (2) the furnishing of a form of proxy to security holders under circumstances reasonably calculated to result in a procurement of proxies: Provided, however, that the term does not apply to the furnishing of a form of proxy to a security holder upon the unsolicited request of such security holder, and does not apply to the performance by the issuer of acts required by Rule $\mathrm{X}-\mathrm{I} 4 \mathrm{~A}-6$ or the performance by any person of ministerial acts on behalf of a person soliciting a proxy.

(c) The term "proxy statement" means the statement required by rule $\mathrm{X}-\mathrm{I}_{4} \mathrm{~A}-\mathrm{I}$, whether or not contained in a single document.

(d) The term "issuer" means the issuer of the security in respect of which the proxy is solicited.

(e) The term "associate," used to indicate a relationship with any person, means (r) any corporation or organization (other than the issuer) of which such person owns of record or beneficially to per cent or more of any class of voting securities, (2) any firm of which such person is a partner, and (3) any relative or spouse of such person having the same home as such person.

$(f)$ The term "affiliate," used to indicate a relationship with any person, means a person controlling, controlled by, or under common control with, such person.

(g) The term "officer" means a chairman of the board of directors, president, vicepresident, treasurer, secretary, comptroller and any other person performing similar functions.

(h) The phrase "the persons making the solicitation," used in relation to a solicita- 
tion by the management of the issuer, means the directors and officers of the issuer, exclusive of any directors or officers who are opposed to the solicitation.

(i) The phrase "matters to be acted upon pursuant to the proxy," used in relation to a proxy other than one which designates an agent or agents to cast a vote or votes in a meeting of security holders, means the matters in respect of which the proxy is solicited. Employed in relation to a proxy to be used at a meeting of security holders, the phrase means the matters which the persons making the solicitation intend to present and any matters which the persons making the solicitation are informed other persons intend to present for action at such meeting, in the event the persons making the solicitation intend that the proxy shall be used for purposes of a vote upon such matters or for purposes of a quorum supporting such a vote: Provided, however, that the phrase as so employed does not apply to the matter of an election to any office which the persons making the solicitation are informed other persons intend to present for action at such meeting if the persons making the solicitation are themselves proposing the election of a nominee to such office and are including in the proxy statement the information regarding the candidacy of such nominee which is required by Schedule I4A.

\section{SCHEDULE 14A}

\section{Items of Information In Proxy Statement UNDER RULe X-I4A-I}

D. MATTERS TO BE ACTED UPON PURSUANT TO THE PROXY

\section{Item 6:}

(a) If action is to be taken with respect to the election of directors or other officials (other than inspectors of election and similar officials)-

(I) Name the offices to be filled by election.

(2) Furnish the following information as to each person (hereinafter called "nominee") for whom it is intended that a vote will be cast for election to any such office pursuant to the proxy:

(A) If the nominee received, in all his capacities, one of the three highest aggregate amounts of remuneration paid by the issuer and any subsidiaries of the issuer (directly, or indirectly through any affiliate of the issuer or otherwise) to any director, officer or employee of the issuer during the last fiscal year of the issuer, state the amount of such remuneration. The information should be given on an accrual basis if practicable. Insofar as such information relates to securities, options to purchase securities, or other property given for services, or to options to purchase securities, given for services, which were exercised or sold by the grantee during the last fiscal year of the issuer, or to remuneration paid to partnerships in which the nominee participated as a member of the partnership, it shall be stated separately.

(B) State, as of the most recent practicable date, the approximate amount of each class of securities of the issuer of which the nominee is directly or indirectly the beneficial owner. If the nominee is not the beneficial owner of any securities of the issuer, make a statement to that effect.

(C) Describe briefly any substantial interest, direct or indirect, of the nominee, and any associates of the nominee, in any property acquired within 2 years or proposed to be acquired by the issuer or any of its subsidiaries, other than property acquired in the ordinary course of business or on the basis of bona 
fide competitive bidding. State the cost of the property to the issuer or subsidiary and the cost to the vendor if the property was acquired by the vendor within 2 years prior to the acquisition by the issuer or subsidiary.

(D) If, combining securities held of record but not owned beneficially and securities owned beneficially whether or not held of record, more than Io\% of the outstanding voting securities of the issuer, or more than 10\% of any class of securities of the issuer not entitled to vote, are held by the nominee and any associates of the nominee, state, as of the most recent practicable date, the approximate aggregate amount of each class of securities of the issuer held by the nominee and such associates and name each associate whose holdings in such class constitute a substantial portion of such aggregate amount. If desired, the character of the interest of the nominee or any associate in the securities of the issuer stated pursuant to this paragraph may be set forth.

(E) If the nominee is a director, officer, partner or employee of any principal underwriter of securities of the issuer or any subsidiary or predecessor of the issuer which have been sold within five years by the issuer, such subsidiary or predecessor, or by any affiliate of the issuer, such subsidiary or predecessor, or if the nominee is directly or indirectly the beneficial owner of more than 10\% of any class of equity securities of any such underwriter, make a statement to that effect, naming the underwriter and stating, as of the most recent practicable date, the approximate amount of each class of securities of the issuer of which such underwriter is directly or indirectly the beneficial owner and the approximate amount of each class of any securities of the issuer which are otherwise held by such underwriter.

(F) If the candidacy of the nominee, for election or reelection to office as the case may be, is the subject of an arrangement or understanding (inclusive of any arrangement or understanding continuing in effect from a time past) directly or indirectly between any of the persons making the solicitation or the nominee and any other person or persons except directors and officers of the issuer acting solely in that capacity, make a statement to that effect, naming each such other person and stating, as of the most recent practicable date, the approximate amount of each class of securities of the issuer of which such person is directly or indirectly the beneficial owner and the approximate amount of each class of any securities of the issuer which are otherwise held by such person: Provided, however, that if such person be a person having a managerial contract with the issuer there shall also be stated, on an accrual basis if practicable, the aggregate amount of remuneration paid by the issuer and any subsidiaries of the issuer (directly, or indirectly through any affiliate of the issuer or otherwise) to such person in all capacities during the last fiscal year of the issuer; Provided further that if such person be a committee representing security holders of the issuer, there shall be stated the approximate amount of each class of securities of the issuer of which each member of the committee is directly or indirectly the beneficial owner and the approximate amount of each class of such securities represented by the committee.

(3) State the aggregate amount of remuneration paid, during the last fiscal year of the issuer, by the issuer and any subsidiaries of the issuer (directly, or indirectly through any affiliate of the issuer or otherwise) to the directors and officers of the 
issuer, considered as a group, and to any person having a managerial contract with the issuer, for services in all capacities. The information should be given on an accrual basis if practicable. Insofar as such information relates to securities, options to purchase securities, or other property given for services, or to options to purchase securities, given for services, which were exercised or sold by the grantees during the last fiscal year of the issuer, or to remuneration paid to partnerships in which directors or officers of the issuer participated as members of the partnership, it shall be stated separately.

(b) If action is to be taken with respect to the election of anditors, or if it is proposed that particular auditors shall be recommended for selection by any committee to select anditors for which votes pursuant to the proxy are to be cast-

(I) Name the auditors.

(2) Describe briefly any material relationship of such auditors and any associates of such auditors to the issuer and any affiliates of the issuer.

(3) State, or describe briefly, (A) the name of each nominee for any committee to select auditors for which votes pursuant to the proxy are to be cast, (B) the office, if any, which such nominee holds with the issuer, (C) the approximate amount, as of the most recent practicable date, of each class of securities of the issuer of which such nominee is directly or indirectly the beneficial owner, and (D) any other relationship of such nominee, or any relationship of any associate of such nominee, to the issuer and any affiliates of the issuer which is of a material character. If the nominee is not the beneficial owner of any securities of the issuer, make a statement to that effect.

Item 13 . If action is to be taken with respect to the restatement of any asset, capital or surplus account of the issuer-

(a) State the nature of the restatement and the date as of which it is to be effective.

(b) Summarize briefly the reasons for the restatement and for the selection of the particular effective date.

(c) State the name and amount of each account (including any reserve accounts) affected by the restatement and the effect of the restatement thereon.

(d) To the extent reasonably practicable, state whether and the extent, if any, to which, by creation of additional surplus or elimination of charges against income, the restatement will as of the date thereof or in the future make available for distribution to the holders of equity securities of any class funds from the treasury of the issuer which could not otherwise be used for such purpose.

E. MATTERS TO BE PRESENTED TO ANY MIEETING OF SECURITY HOLDERS AT WHICH ACTION PURSUANT TO THE PROXY IS TO BE TAKEN BUT WHICH ARE NOT TO BE ACTED UPON PURSUANT TO THE PROXY

Item 16 . If the persons making the solicitation are informed that any other person intends to present any matter for action at any meeting of security holders at which action pursuant to the proxy is to be taken, and if the persons making the solicitation intend that such matter shall not be acted upon pursuant to the proxy, make a statement to that effect, identifying the matter and indicating the disposition proposed to be made thereof at the meeting in the event the disposition thereof is within the control of the persons making the solicitation. 